\title{
PERAN MAHASISWA DALAM PENJAMINAN MUTU PERGURUAN TINGGI
}

\author{
Muhlisa*)
}

\section{PENDAHULAUN}

Penjaminan mutu perguruan tinggi adalah proses perencanaan, pemenuhan, pengendalian, dan pengembangan standar pendidikan tinggi secara konsisten dan berkelanjutan, sehingga pemangku kepentingan (stakeholders) internal dan eksternal perguruan tinggi, yaitu mahasiswa, dosen, karyawan, masyarakat, dunia usaha, asosiasi profesi, pemerintah memperoleh kepuasan atas kinerja dan keluaran perguruan tinggi.

Tujuan penjaminan mutu perguruan tinggi adalah terjaminnya mutu penyelenggaraan pendidikan tinggi baik pada masukan, proses, maupun keluaran berdasarkan peraturan perundang-undangan, nilai dasar, visi, dan misi perguruan tinggi. Kegiatan penjaminan mutu ini merupakan perwujudan akuntabilitas dan transparansi perguruan tinggi. Hal ini sejalan dengan Undang-undang No. 20 tahun 2003 tentang Sistem Pendidikan Nasional pasal 51 ayat 2, dimana pengelolaan satuan pendidikan tinggi dilaksanakan berdasarkan prinsip otonomi, akuntabilitas, jaminan mutu, dan evaluasi yang transparan. Selain itu dipertegas dengan Peraturan Menteri Pendidikan dan Kebudayaan Republik Indonesia No. 49 tahun 2014 tentang Standar Nasional Pendidikan, dimana perguruan tinggi wajib melakukan penjaminan mutu pendidikan sebagai tanggung jawabnya kepada stakeholders, untuk mememuhi Standar Pendidikan Tinggi yang terdiri atas standar nasional pendidikan tinggi (SN Dikti) yang ditetapkan oleh Menteri yang terdiri atas standar nasional pendidikan, standar penelitian dan standar pengabdian kepada masyarakat, kemudian standar pendidikan tinggi yang ditetapkan oleh setiap perguruan tinggi yang terdiri dari standar dalam bidang akademik dan standar dalam bidang non akademik.

Pelaksanaan penjaminan mutu pendidikan tinggi seperti yang diamanatkan oleh Undang-undang No.12 tahun 2012 bertujuan untuk mewujudkan perguruan tinggi yang bermutu, yang dapat menghasilkan lulusan yang mampu secara aktif mengembangkan potensinya dan menghasilkan Ilmu Pengetahuan dan/atau Teknologi yang berguna bagi Masyarakat, bangsa, dan negara.

\section{PEMBAHASAN}

\section{Mahasiswa Dan Penjaminan Mutu Perguruan Tinggi}

Mutu sebuah perguruan tinggi tidak hanya ditentukan oleh aspek mutu dosen dan tenaga kependidikan saja, tetapi juga oleh mutu mahasiswa yang menjalani pendidikan di perguruan tinggi tersebut. Indikasi mutu mahasiswa antara lain adalah tingkat keketatan dalam seleksi masuk, kepatuhan mahasiswa terhadap etika, sikap proaktif mahasiswa dalam proses belajar mengajar, prestasi akademik yang ditunjukkan, dan yang terutama adalah kompetensi lulusan yang handal.

Ada banyak hal yang mungkin kurang disadari oleh para mahasiswa tentang peran penting yang dimilikinya, padahal sebenarnya sangat mempengaruhi terbentuknya mutu sebuah perguruan tinggi. Satu peran penting yang dapat dijalankan mahasiswa adalah pelayanan yang harus diberikan oleh mahasiswa kepada para pemangku kepentingan (stakeholder) lainnya, karena mahasiswa adalah salah satu unsur yang terlibat dalam penyelenggaraan perguruan tinggi. Jadi mahasiswa tidak hanya sebagai pihak yang dilayani, tetapi juga sebagai pihak yang harus melayani. Mahasiswa seperti halnya dosen harus menjaga mutu dengan kehadirannya tepat waktu di kelas, wajib mengerjakan tugas dengan sebaik-baiknya, mematuhi etika yang diterapkan, juga mahasiswa diberi akses untuk menyampaikan informasi kepada pihak-pihak yang berkepentingan terhadap penjaminan mutu perguruan tinggi tentang adanya dosen atau tenaga kependidikan yang dipandang kontra produktif terhadap penjaminan mutu (misalnya dosen sering tidak masuk tanpa menggati di waktu yang lain, staf laboran yang tidak siaga di laboratorium ketika kegiatan praktikum berlangsung, dll). Oleh karena itu seharusnya mahasiswa juga dilibatkan dalam pelaksanaan sistem penjaminan mutu perguruan tinggi (SPM-PT) yang dilaksanakan di tingkat perguruan tinggi dan program studi. Sistem penjaminan mutu perguruan tinggi memerlukan komitmen bersama dari semua sivitas akademika mulai pimpinan puncak sampai pelaksana paling bawah (misalnya 
petugas kebersihan, petugas pengamanan, petugas parkir, dll). Karena mahasiswa merupakan salah satu unsur penting yang dapat menopang keberhasilan pelaksanaan sistem penjaminan mutu di perguruan tinggi, maka sosialisasi kepada semua sivitas akademik harus memasukkan unsur mahasiswa sebagai salah satu sasaran sosialisasi yang harus dilaksanakan tecara terus-menerus melalui berbagai media komunikasi dan disampaikan pada berbagai kesempatan. Melalui sosialisasi tersebut diharapkan memperoleh komitmen bersama dalam melaksanakan penjaminan mutu perguruan tinggi sehingga seluruh pihak memperoleh dorongan mental untuk terus memperbaiki diri agar memperoleh kinerja akademik yang maksimal.

Melalui sosialisasi yang terus-menerus tersebut, setidaknya akan ada sanksi sosial jika ada unsur-unsur yang terlibat dalam pelaksanaan penjaminan mutu perguruan tinggi melakukan tindakan-tindakan yang kontra produktif karena sistem penjaminan mutu perguruan tinggi (SPM-PT) ini diketahui oleh semua pihak. Upaya untuk meningkatkan dan menjaga mutu yang baik tidaklah mudah. Selain perlu upaya terus menerus dari pihak perguruan tinggi dalam membangun sistem yang mendukung penjaminan mutu, juga diperlukan kesadaran setiap pribadi yang ada di dalamnya, dan tidak akan maksimal hasilnya kalau dipaksakan. Jadi harus ada kesadaran dari pribadi masing-masing, dan kemudian merasakan bahwa meningkatkan mutu dan menjaganya adalah sebuah kebutuhan yang muncul dari dalam diri sanubari.

Salah satu peran mahasiswa dalam sistem penjaminan mutu tergambar pada evaluasi diri program studi, seperti pada evaluasi diri yang dilakukan di Universitas Brawijaya yang menyebutkan dalam evaluasi dirinya bahwa mahasiswa memiliki peran penting dalam penciptaan suasana akademik yang sehat, tidak pernah terdengar atau timbulnya demonstrasi, apalagi bentrokan antar mahasiswa hal ini menunjukan tata hubungan yang baik. Interaksi sosial mahasiswa dalam kampus, dalam beraktivitas di unit kegiatan mahasiswa yang melibatkan berbagai unsur mahasiswa, ikut mendorong interaksi positif dalam penciptaan suasana akademik.

\section{Peran Mahasiswa Dalam Peningkatan Mutu Perguruan Tinggi}

Berhubungan dengan hal tersebut, dorongan kepada mahasiswa agar memahami perannya dalam membantu meningkatkan mutu perguruan tinggi (almamaternya) menjadi sangatlah penting. Banyak cara yang dapat dilakukan mahasiswa dalam mendukung mutu perguruan tinggi tersebut yaitu dengan berusaha mendukung tepenuhinya standar mutu yang telah ditetapkan, beberapa diantaranya adalah:

1. Mahasiswa terlibat aktif dalam proses pembelajaran

2. Mahasiswa berperan aktif dalam menciptakan atmosfir akademik yang kondusif.

3. Mahasiswa mencapai kematangan akademik dan kebebasan berpikir sehingga dapat melaksanakan aktivitas intelektual secara maksimal.

4. Mahasiswa memahami perkembangan Ilmu pengetahuan, teknologi dan mencari informasi langsung ke sumbernya.

5. Mahasiswa mampu menggunakan pengetahuan untuk menyelesaikan masalah.

6. Mahasiswa mampu mengkomunikasikan pengetahuan kepada pihak lain.

7. Mahasiswa dapat mengembangkan belajar mandiri dan belajar kelompok.

8. Mahasiswa banyak terlibat dalam penelitian dosen/lembaga.

9. Mahasiswa berperan serta dalam menjaga kemanan, keindahan, dan kebersihan lingkungan kampus.

10. Mahasiswa melaksanakan pembimbingan akademik secara berkala.

11.Mahasiswa ikut berpartisipasi dalam mendesain, mengelola dan mengevaluasi kurikulum

12. Mahasiswa melakukan evaluasi diri untuk mencapai kompetensi lulusan program studi.

13. Mahasiswa berpartisipasi aktif dalam organisasi mahasiswa dan kegiatan ekstrakurikuler, dll

Untuk itu pengelola pendidikan harus memaknai dan selalu senantiasa mendorong peran mahasiswa dalam meningkatkan mutu pada suatu program studi. 


\section{DAFTAR PUSTAKA}

Dikti. 2014. Pedoman Sistem Penjaminan Mutu Pendidikan Tinggi. Kementerian Pendidikan dan Kebudayaan

.2014. Buku Kurikulum Pendidikan Tinggi. Kementerian Pendidikan dan Kebudayaan.

Lembaga Penjaminan Mutu UNJ. 2012. Profil Lembaga Penjaminan Mutu. Universitas Negeri Jakarta

FIP. 2014. Peran mahasiswa dalam penjaminan mutu Perguruan Tinggi. Universitas Negeri Surabaya.

Evaluasi Diri. 2008. Universitas Brawijaya 
